\title{
Determinants of acceptance of an illness in the case of patients suffering from psoriasis treated in the hospital and outpatient clinic settings
}

\begin{abstract}
BACKGROUND
Psoriasis is one of the most commonly occurring cutaneous conditions. In connection with its chronic character, and with the presence of defacing pathological changes on the skin, this medical condition reduces the quality of life in the physical, mental and social aspects. It is also an illness whose course is substantially influenced by psychological factors. The level of acceptance of an illness in the case of psoriasis patients may exert a significant influence on their level of adjustment to their medical condition and psycho-social functioning. The objective of this research was to estimate the level of acceptance of the illness, and to determine the correlations between acceptance of the illness and the way in which it is perceived, the exacerbation of symptoms, and the health locus of control in groups of patients with psoriasis treated in the hospital and outpatient clinic settings.
\end{abstract}

PARTICIPANTS AND PROCEDURE

The research included a group of 61 patients suffering from psoriasis. The following research tools were applied: the Acceptance of Illness Scale (AIS), the Multidimensional Health Locus of Control Scale (MHLC), the Disease Rating Scale (DRS), the Self-Administered Psoriasis Area Severity Index (SAPASI), and the Visual Analogue Scale (VAS).

\section{RESULTS}

The studied patients accepted their illness to an average degree. No significant differences were found for that vari- able between the studied individuals treated in the hospital setting and those treated in the outpatient clinic setting. In the group of hospitalized patients, the perception of the illness in the categories of a threat, harm, life balance disturbance and an obstacle/a loss was negatively correlated with the acceptance of it. In the group of patients treated in the outpatient clinic setting, the assessment of the illness in the categories of a threat and harm, and the subjective assessment of exacerbation of symptoms of the illness, measured using the VAS, were negatively correlated, whereas being convinced that the health locus of control was located internally was positively correlated with acceptance of the illness. The perception of an illness as an obstacle and being convinced that the health locus of control is the internal one make it possible to predict the degree of acceptance of an illness in the case of patients suffering from psoriasis.

\section{CONCLUSIONS}

Planning psychological influences, and wanting to understand the functioning of individuals suffering from psoriasis better, it is recommendable to concentrate upon the understanding of the possible modification of the way in which the individuals in question assess their own illness, and also their own influence upon their state of health.

KEY WORDS

psychodermatology; acceptance of an illness; psoriasis

organizations - Institute of Psychology, University of Łódz, Łódź, Poland

aUthors' Contribution - A: Study design - B: Data collection - C: Statistical analysis - D: Data interpretation .

E: Manuscript preparation · F: Literature search · G: Funds collection

Corresponding AUthor - Joanna Miniszewska, Ph.D., Institute of Psychology, University of Łódz, Smugowa 10/12 Str., 91-433 Łódź, Poland, e-mail: jminisz@poczta.onet.pl

TO CITE THIS ARTICLE - Adamska, M., \& Miniszewska, J. (2016). Determinants of acceptance of an illness in the case of patients suffering from psoriasis treated in the hospital and outpatient clinic settings. Health Psychology Report, 4(1), 54-64. doi: 10.5114/hpr.2015.53958

RECEIVED 20.12.2014 · REVIEWED 09.01.2015 · ACCEPTED 22.01.2015 · PUBLISHED 30.09.2015 


\section{BACKGROUND}

A chronic somatic illness is usually connected with experiencing numerous objective and subjective inconveniences. In the former group, it is possible to include, first and foremost, a change in lifestyle, a constant contact with medical care facilities, and it being necessary to receive a medication, or to conduct medical procedures on one's own for extended periods of time. Subjective inconveniences are connected, in turn, with experiences of a mental and spiritual character, which are triggered by an illness (Orzechowska, Talarowska, Zboralski, Florkowski, \& Gałecki, 2013). The situation of chronically ill individuals is, as a general rule, highly heterogeneous and dependent, among other things, on the clinical picture, the period of time during which an ill individual is excluded from normal life in connection with being hospitalized or with therapeutic procedures, the duration of treatment, and the method of it. The occurrence of every chronic illness and the treatment of it makes an ill individual confronted with an extremely difficult task - the necessity of adjusting to the requirements and restrictions which are part and parcel of an illness. Adaptation to a chronic, recurrent somatic illness is, therefore, a complex and complicated process. It requires, first of all, that one should accept the fact of being ill and all and any restrictions connected with the state of health, and, secondly, that they should take advantage of, and activate, the personal resources which are at one's own disposal and which will support the process of adaptation. In turn, acceptance of the state of health is dependent on the way in which a human being perceives their illness. In the case of dermatological illnesses, an additional difficulty in the scope of adaptation is the visible character of changes afflicting the skin, and it being necessary to confront the reactions of other people (Heszen \& Sęk, 2012; Papadopoulos \& Bor, 1999; Walker \& Papadopoulos, 2005).

Psoriasis, being one of the most common skin illnesses, is an illness having a complex aetiology, in which a significant role is played by genetic background. The course of an illness is a chronic and recurrent one, and the major feature of it is the increased proliferation of the epidermis (consisting in the eight-fold shortening of the duration of the cell-division cycle) and exfoliating papular rash. The morphological picture is very diverse, and so is the exacerbation of changes, from a few afflicted areas restricted to particular regions, including the severe forms afflicting the entire skin and the joints, and even resulting in becoming disabled. A significant influence on the provocation of the medical condition is exerted by various initiating factors (damage to the skin, infections, certain medication, and stress), in connection with which fact it is comparatively dif- ficult to control the state of health (Pacan, Szepietowski, \& Kiejna, 2002; Jabłońska \& Majewski, 2005). As it can be concluded from a number of studies, psoriasis significantly deteriorates the quality of life; the European Federation of Psoriasis Patient Associations (EUROSPO) has examined 17,990 patients; as many as $77 \%$ reported experiencing problems resulting from psoriasis (Dubertret et al., 2006).

The majority of studies concerning the functioning and adjustment to illness are relevant to individuals staying in hospital facilities. That results from the fact, among others, that it is comparatively less difficult to gain access to them. However, it needs to be pointed out that the mode of treatment (in the hospital or outpatient clinic setting) undeniably requires patients to activate slightly different resources and ways of becoming adjusted. In connection with the fact referred to above, it is recommendable to search for those variables among various factors which are connected with the acceptance of psoriasis depending on the applied mode of treatment. Identifying them will make it possible to predict the degree of adaptation to the medical condition, and it may also become the foundation for developing guidelines for psychotherapeutic work with individuals suffering from psoriasis depending on the setting in which they are treated.

\section{OBJECTIVE OF RESEARCH}

The objective of the conducted research was to estimate the level of acceptance of the illness in the groups of individuals treated in the hospital and outpatient clinic settings, and to determine correlations between the way in which one's illness is perceived, the exacerbation of the symptoms of it, and the health locus of control and the degree of acceptance of the illness in the studied groups. An attempt was made as well to determine the predictors of acceptance of an illness.

The following research questions were asked accordingly:

1. Do hospitalized patients differ from those treated in the outpatient clinic setting in the scope of acceptance of their illness?

2. Is the level of exacerbation of psoriatic changes connected with acceptance of the illness in the studied groups?

3. Does the membership of the group of hospitalized patients and patients treated in the outpatient clinic setting differentiate patients in the aspect of the health locus of control and the way in which their illness is assessed by them?

4. Is the health locus of control, the way in which one's illness is perceived, and the exacerbation of the latter connected with acceptance of the illness in the studied groups?
Determinants of psoriasis acceptance 
5. Is it possible to identify predictors of acceptance of an illness in the collection of variables being analysed?

\section{PARTICIPANTS AND PROCEDURE}

\section{STUDIED INDIVIDUALS}

The study encompassed a group of psoriasis patients treated at the Clinic of Dermatology and Venereology of the Medical University of Łódź, and at
Marta Adamska, Joanna Miniszewska Non-public Health Care Facility 'Medicus' in Ryki. The study was participated in solely by individuals treated using the standard methods (with the exclusion of patients treated using biological means). The study was approved by the Commission of Bioethics of the Medical University of Łódź (No. UŁ/1/10/2012). The consent of the patients to participate in the study was obtained. The participants had been informed about the objective, the subject and the course of the study, and expressed their consent to participate in it.

Table 1

Profile of the studied group

\begin{tabular}{lcc}
\hline $\begin{array}{l}N=61 \\
\text { Membership of the group }\end{array}$ & $n$ \\
$\begin{array}{l}\text { hospital } \\
\text { outpatient clinic }\end{array}$ & 33 & 54.10 \\
Sex & 28 & 45.90 \\
females & \\
males & 39 & 63.90 \\
Changes in visible places on the body & \\
yes & 22 & 36.10 \\
no & 55 & 90.20 \\
& 6 & 9.80
\end{tabular}

Psoriasis in other family members

$\begin{array}{lll}\text { yes } & 29 & 47.50 \\ \text { no } & 32 & 52.50\end{array}$

Exacerbation of the illness (SAPASI)

Results:

$\begin{array}{lll}\text { low }(0-6) & 23 & 37.70 \\ \text { average (6-18) } & 22 & 36.10 \\ \text { high }(>18) & 16 & 26.20\end{array}$

Exacerbation of the illness (VAS)

Results:

\begin{tabular}{lll} 
low $(0-40)$ & 25 & 41.00 \\
average $(40-64)$ & 18 & 29.50 \\
high $(>64)$ & 17 & 27.90 \\
\hline
\end{tabular}

A group of 61 patients (39 female and 22 male) aged from 18 to 82 (average age $47, S D=16.22$ ) was studied. In $90.20 \%$ of the patients, psoriatic changes occurred in the visible parts of the body. In $47.50 \%$, psoriasis occurred in other members of their families as well. The studied group of psoriasis patients was divided into two subgroups. The first one consisted of hospitalized patients (33 individuals), whereas the second one consisted of patients treated in the outpatient clinic setting (28 individuals). The profile of the group is presented in detail in Table 1.

\section{RESEARCH TOOLS AND STATISTICAL ANALYSES}

For the purpose of measurement of the degree of acceptance of the illness, the Acceptance of Illness Scale was applied. It is the adaptation of the Acceptance of Illness Scale, the authors of which are Felton, Revenson and Hinrichsen. The author of the Polish adaptation is Juczyński. The scale is composed of 8 statements, describing the negative consequences of the bad state of health, which can be reduced to the recognition of the restrictions imposed by the illness, the lack of self-sufficiency, the feeling of dependence on other people, and the lowered level of self-esteem. The acceptance of an illness is the evidence of the lower level of the intensity of negative reactions and emotions. The scale is intended to be applied in studies on adult individuals who are currently ill. It may be applied in researching acceptance in the case of every single illness. The studied individual determines their current state using a five-degree scale, in which the most positive answer is: 1 - I definitely agree, and the least positive one is: 5 - I definitely disagree. A definite agreement means maladjustment to the illness, whereas the definite lack of agreement expresses the acceptance of it. The result is calculated by summing up the entire score. The general scope of the degree of acceptance of an illness is situated within the range between 8 and 40 points. A low result means the lack of acceptance of an illness and adjustment to it, and a high level of the feeling of mental discomfort, whereas a high level indicates acceptance of one's illness and a lack of negative emotions connected with the illness. The reliability of the Polish version is similar to that of the original. For the latter, Cronbach's $\alpha$ is .82, whereas the constancy index over the period of seven months is .69 (Juczyński, 2001).

In the study, the Multidimensional Health Locus of Control Scale developed by Wallston, Wallston and DeVellis, in the adaptation of Juczyński, was also applied. The scale is composed of 18 statements, and it is applied for the measurement of convictions concerning generalized expectations in the three di- 
mensions of the health locus of control: the external dimension - control over one's own health depends on me; the influence of other people - influence on health is exerted by other people, in particular, by medical personnel; chance - the state of health depends on chance and other external factors. The studied individual expresses their opinions about the presented statements using a six-degree scale, in which the most positive answer is: I definitely disagree (1 point), and the least positive one is: I definitely agree (6 points). The results are calculated by summing up the points for each of the scales separately, and the lowest possible score is 6 , whereas the highest one is 36 . The higher the result, the stronger is the conviction that a given factor does influence the state of health (Juczyński, 2001).

The analysis of the way in which one's illness is perceived was conducted using the Disease Rating Scale. That scale was developed at the Chair of Clinical Psychology of Adults of the Catholic University in Lublin, and the authors are Janowski and Steuden. That scale is a survey-based method for the investigation of the subjective meanings which are assigned by a patient to their illness. The theoretical foundation for the development of that tool was the concept of the initial situation assessment of Lazarus and Folkman, which was extended by the authors by means of adding the view of the perception of an illness of Lipowski (Janowski, Steuden, Kuryłowicz, \& Nieśpiałowska-Steuden, 2009). The scale is composed of 47 statements which are collated in 7 subscales. The subscales express the various categories of meanings, which can be assigned by the patients to the situation of their illness: Threat, Benefit, Obstacle/Loss, Challenge, Harm, Value and Meaning. The scale is intended to be applied for studying adult individuals. A patient expresses their opinion about the provided statements using a five-degree scale (yes - 5 points, probably yes -4 points, I do not know 3 points, probably no -2 points, no -1 point). Some of the questions were formulated as negative in order to prevent the answers from becoming biased (yes 1 point [...], not - 5 points). Raw results are calculated by summing points for all scales. The test may be applied both in scientific research and in clinical practice. The values of reliability coefficients (Cronbach's $\alpha$ ) for separate subscales are between .64 and .87 (Janowski et al., 2009; Janowski, 2006).

The SAPASI scale is a specialist tool applied for the measurement of exacerbation of psoriatic changes on the skin which is subjectively experienced by a patient. The scale is composed of a picture presenting the front and back of a human silhouette in which a patient is requested to indicate the regions of the body currently afflicted by the illness. The result is obtained on the basis of the number of regions of the body afflicted by pathological changes on the contour of the silhouette marked by a patient. The
SAPASI is also composed of 3 visual analogue scales, in which a patient estimates the colour, thickness and the degree of exfoliation of changes on the skin using a five-degree scale.

The smallest number of points which can be obtained is 0 , whereas the largest one is 72 (Sampogna et al., 2003; Sampogna, Tabolli, \& Abeni, 2007).

The Visual Analogue Scale (VAS) is a scale making it possible to conduct the general assessment of the state of health, or, alternatively, of the activity of an illness in the range between 0 and 100. It is most frequently presented in the form of a horizontal line the length of which is $100 \mathrm{~mm}$, on which the patients mark, with a vertical stroke, the subjectively experienced degree of the exacerbation of an illness. The result is obtained by measuring (in millimetres) the distance between the beginning of the scale and the place which was marked by a patient (Kulczycka, Sysa-Jędrzejowska, \& Robak, 2007).

The analysis of the results was conducted using the SPSS 20 program using the significance test of differences between means (Student's $t$-test), the ANOVA test, and the Pearson correlation test and the multiple step analysis of regression.

\section{RESULTS}

The analysis of the level of acceptance of the illness showed that patients suffering from psoriasis accept their illness to an average degree. The average results in the area of that variable were slightly higher in the group of outpatient clinic patients, but they did not differ statistically significantly from the results obtained by hospitalized patients (Table 2).

It was found that the subjective assessment of exacerbation of pathological changes on the skin did not differentiate the studied patients, either, in the aspect of acceptance of the illness. The patients whose subjectively estimated exacerbation of psoriasis was measured using the SAPASI and VAS were not different from one another in that variable (Table 3).

The obtained results concerning the conviction about the health locus of control also indicate a lack of significant differences in that variable in the studied groups of patients suffering from psoriasis. Even though hospitalized patients were convinced that the influence on their health is principally exerted by the actions of other people, whereas outpatient clinic patients were utterly convinced that the influence on the state of their health was of a more internal character, it was found that those differences were not statistically significant (Table 4).

Furthermore, no differences in the scope of the perception of one's illness in dependence on the mode of treatment were ascertained. Therefore, it was not ascertained that the patients in the studied groups perceived the illness in different ways, most
Determinants of psoriasis acceptance 
Table 2

Average values of acceptance of the illness in the studied groups of outpatient clinic and hospitalized patients

\begin{tabular}{lcccc}
\hline & \multicolumn{4}{c}{ Acceptance of the illness } \\
\cline { 2 - 4 } & $M$ & $S D$ & $t$ & $p$ \\
\hline Hospital, $n=33$ & 26.55 & 8.00 & -0.37 & .716 \\
Outpatient clinic, $n=28$ & 27.25 & 6.84 & & \\
\hline
\end{tabular}

Table 3

Marta Adamska, Joanna Miniszewska

Average values of acceptance of the illness dependent on the subjective assessment of exacerbation

\begin{tabular}{|c|c|c|c|c|c|}
\hline SAPASI & \multicolumn{3}{|c|}{ Acceptance of the illness } & \multicolumn{2}{|c|}{ ANOVA } \\
\hline Results & $n$ & $M$ & $S D$ & $F$ & $p$ \\
\hline low & 23 & 29.22 & 6.35 & 1.92 & .156 \\
\hline average & 22 & 25.64 & 8.19 & & \\
\hline high & 16 & 25.19 & 7.38 & & \\
\hline total & 61 & 26.87 & 7.44 & & \\
\hline VAS & \multicolumn{3}{|c|}{ Acceptance of the illness } & \multicolumn{2}{|c|}{ ANOVA } \\
\hline Results & $n$ & $M$ & $S D$ & $F$ & $p$ \\
\hline low & 25 & 28.56 & 7.36 & 0.10 & .375 \\
\hline average & 18 & 25.89 & 6.06 & & \\
\hline high & 17 & 25.71 & 8.87 & & \\
\hline total & 60 & 26.95 & 7.74 & & \\
\hline
\end{tabular}

Table 4

Average values in the scope of the health locus of control and perceiving one's illness in the studied groups of outpatient clinic and hospitalized patients

\begin{tabular}{|c|c|c|c|c|c|c|}
\hline \multirow{2}{*}{$\begin{array}{l}\text { Health locus } \\
\text { of control }\end{array}$} & \multicolumn{2}{|c|}{ Hospital, $n=33$} & \multicolumn{2}{|c|}{ Outpatient clinic, $n=28$} & \multirow[t]{2}{*}{$t$} & \multirow[t]{2}{*}{$p$} \\
\hline & $M$ & $S D$ & $M$ & $S D$ & & \\
\hline internal & 23.94 & 5.56 & 23.21 & 4.90 & 0.54 & .594 \\
\hline $\begin{array}{l}\text { influence } \\
\text { of others }\end{array}$ & 24.00 & 5.95 & 22.96 & 6.11 & 0.67 & .506 \\
\hline chance & 20.52 & 6.36 & 21.11 & 5.45 & -0.39 & .700 \\
\hline \multirow{2}{*}{$\begin{array}{c}\text { Illness } \\
\text { as }\end{array}$} & \multicolumn{2}{|c|}{ Hospital, $n=33$} & \multicolumn{2}{|c|}{ Outpatient clinic, $n=28$} & $t$ & $p$ \\
\hline & $M$ & $S D$ & $M$ & $S D$ & & \\
\hline threat & 23.94 & 9.41 & 23.43 & 9.38 & 0.21 & .833 \\
\hline benefit & 14.30 & 5.74 & 12.43 & 4.60 & 1.39 & .170 \\
\hline challenge & 19.09 & 5.58 & 19.57 & 5.05 & -0.35 & .728 \\
\hline harm & 18.33 & 7.71 & 20.39 & 6.59 & -1.11 & .271 \\
\hline value & 14.76 & 5.57 & 14.18 & 6.24 & -0.38 & .703 \\
\hline meaning & 17.42 & 4.62 & 17.71 & 4.69 & -0.24 & .809 \\
\hline $\begin{array}{l}\text { obstacle/ } \\
\text { loss }\end{array}$ & 21.36 & 10.20 & 21.68 & 9.91 & -0.12 & .904 \\
\hline
\end{tabular}


frequently assessing it as a threat, and as an obstacle/a loss (Table 4).

In the subsequent stages, correlations between the subjective assessment of the exacerbation of pathological changes on the skin (measured using the SAPASI and VAS), the health locus of control, and the way in which one's illness is perceived and the acceptance of it in the subgroups of patients treated in the hospital and outpatient clinic settings were assessed (Table 5).

In the studied subgroup of patients treated in the outpatient clinic setting, there was found a significant negative correlation of acceptance of the illness with the subjective assessment of exacerbation of psoriatic changes measured using the VAS. The higher the exacerbation of the illness was assessed to be, the less acceptance of their medical condition they expressed.

The conviction that they really could influence their own health was strongly and positively connected with acceptance of the illness in the group of outpatient clinic patients as well - the stronger the conviction of those patients was that the control over their health depended on themselves, the more acceptance of their illness they expressed. In turn, in the group of hospitalized individuals, treating the state of health in the categories of chance was moderately negatively connected with acceptance of the illness, which means that the stronger, among those patients, the conviction was that the state of their health is determined by chance, the less acceptance of the restrictions resulting from psoriasis was expressed.

In both of the subgroups of patients suffering from psoriasis, a correlation was found between the way in which an illness is perceived and the acceptance of it. In the group of hospitalized patients, the perception of their medical condition in the categories of an obstacle (which is the strongest correlation), life balance disturbance, threat and harm was negatively correlated with the acceptance of it. In the group of patients treated in the outpatient clinic setting, it was solely the perception of their medical condition in the categories of threat and harm that negatively correlated with acceptance of the illness.

The final stage of the analyses was an attempt to determine the determinants of acceptance of the illness among the variables being analysed. In connection with the fact that the individuals from the separate subgroups (hospitalized patients and those treated in the outpatient clinic setting) were not different from one another in the level of acceptance of the illness, it was resolved that calculations would be conducted for the entire group of patients. Two variables were found to be predictors of acceptance of the illness. The greatest significance was that of perceiving the illness in the categories of an obstacle/a loss, explaining independently $25 \%$ of the vari- ance. Subsequently, the internal health locus of control was revealed to be significant (explaining $21 \%$ of the variance). Altogether, the obtained model made it possible to predict $46 \%$ of the variability of the results of the studied independent variable. On the basis of the values of the beta indicators, one can conclude that perceiving an illness in the category of an obstacle or a loss resulted in a decrease of the level of acceptance of the illness in the case of the studied individuals. In turn, the stronger was the conviction that there existed an internal locus of control, the higher was the level of acceptance of the illness (Table 6).

\section{DISCUSSION}

The acceptance of an illness determines the degree of adjustment to one's medical condition, and is the determinant of the emotional functioning in an illness. Patients with a high level of acceptance of an illness react better to it, find it easier to recognize and understand the restrictions resulting from that, and experience fewer negative emotions in connection with the presence of the illness. Simultaneously, they are

\section{Table 5}

Correlation coefficients between the subjective assessment of exacerbation of psoriasis, the health locus of control and the way in which the illness is perceived and acceptance of it in the studied groups of hospitalized and outpatient clinic patients

\begin{tabular}{lcc}
\hline & \multicolumn{2}{c}{ Acceptance of the illness } \\
\cline { 2 - 3 } & Hospital & $\begin{array}{c}\text { Outpatient } \\
\text { clinic }\end{array}$ \\
\hline $\begin{array}{l}\text { Exacerbation } \\
\text { of psoriasis (SAPASI) }\end{array}$ & -.27 & -.28 \\
Exacerbation & & $-.43^{*}$ \\
of psoriasis (VAS) & -.01 & $.59^{* *}$ \\
Dimension - control & .23 & .24 \\
internal & -.09 & -.09 \\
influence of others & $-.39^{*}$ & $-.50^{*}$ \\
chance & & -.10 \\
IIIness as & $-.41^{*}$ & -.19 \\
threat & -.30 & $-.39^{*}$ \\
benefit & -.26 & -.18 \\
challenge & $-.42^{*}$ & -.11 \\
harm & -.08 & -.37 \\
value & $-.56^{*}$ & $-.61^{* *}$ \\
meaning & & \\
obstacle/loss & & \\
\hline
\end{tabular}

Note. ${ }^{*} p<.05 ;{ }^{* *} p<.01$
Determinants of psoriasis acceptance 
Table 6

Determinants of acceptance of the illness

\begin{tabular}{lccccc}
\hline & $B$ & $S E B$ & $\beta$ & $t$ & Significance \\
\hline IIIness as an obstacle & -0.25 & 0.10 & -.34 & -2.54 & .013 \\
Internal control & -0.47 & 0.16 & -.33 & -2.99 & .004 \\
Constant value & 27.61 & 4.90 & & -5.64 & $<.001$ \\
Corrected $R^{2}=.33, F(4,56)=8.32$ & & & & & \\
\hline
\end{tabular}

Marta Adamska, Joanna

Miniszewska

able to come to terms with the state of their health, think more realistically, and, in spite of the character of a given affliction (frequently a chronic one), they feel strong, agile and important. It was proved that a higher level of acceptance of an illness is frequently accompanied by a more optimistic approach to life, a lower level of mental discomfort in connection with the ailment, and the application of coping strategies, which are conducive to looking after health (Basinska \& Kasprzak, 2012; Basińska \& Woźniewicz, 2012).

It is also in the group of patients suffering from medical conditions of the skin that the level of acceptance of an illness plays a significant role in better adjustment to the loss of health. There is a lot of research which confirms the significance of the level of acceptance of an illness in the functioning of individuals afflicted by chronic dermatoses. In the case of patients suffering from psoriasis, it was proved that a higher level of acceptance of the illness is connected with a more positive assessment of the quality of life (Miniszewska, 2011; Miniszewska, Juczyński, Ograczyk, \& Zalewska, 2013). It was also proved that patients suffering from psoriasis with a higher level of acceptance of an illness show a lower level of exacerbation of psychopathological symptoms, such as somatization disorders, obsessive-compulsive disorders or anxiety (Kostyła, Tabała, \& Kocur, 2013). That fact may be of particular significance because mental disorders (in particular, depression and anxiety disorders) are reported to occur four times more frequently in individuals suffering from psoriasis than in individuals suffering from other medical conditions of the skin (Parafianowicz et al., 2010). Basińska and Szymańska (2013) indicate in their studies the occurrence of a connection between the traits of psoriasis and mood; consequently, women, younger individuals, those who have been suffering from psoriasis for a shorter period of time, with more exacerbated ailments and a higher percentage of the afflicted surface of the body have, as a major feature of them, a more negative mood in comparison with males, older individuals, those who have been suffering from psoriasis for a longer period of time, with less exacerbated ailments and a smaller area afflicted by changes on the skin.
A high level of acceptance of an illness also means taking advantage of avoidant stress coping strategies, such as discontinuing actions and putting the blame on others, less frequently (Basińska \& Kasprzak, 2012).

The analysis of the obtained results showed that in the studied groups of individuals suffering from psoriasis, which means individuals treated in the hospital setting, and those treated in the outpatient clinic setting, the level of acceptance of the restrictions connected with the illness was average. Furthermore, comparing the results with the average indicators of acceptance (Juczyński, 2001), one can note that the major feature of the studied individuals was the slightly higher acceptance of the illness in comparison with individuals from various clinical groups (among others, of patients suffering from diabetes, migraine, chronic pain and multiple sclerosis). The sole exception consisted of women in whom breast cancer and cervical cancer had been diagnosed (in the case of those women, the level of the results was higher). Needless to say, comparison with other clinical groups is approximate. Nevertheless, it is worth emphasizing in connection with the fact that in the literature of the subject substantial difficulties which are experienced by individuals suffering from psoriasis in their daily life are indicated and highlighted.

It is estimated that the negative influence of psoriasis on the functioning of the patients is comparable with the one exerted by such life-threatening illnesses as medical conditions of the cardiovascular system, neoplasms, diabetes or depression (Hawro, Janusz, Zalewska, \& Miniszewska, 2011; Menter \& Stoff, 2011).

In the present study, it was also found that membership of the group of patients treated in the hospital and outpatient clinic settings does not make the studied individuals different in the scope of accepting their own medical condition. Average results in the scope of that variable were slightly higher in the group of outpatient clinic patients, but they were not significantly different from the results obtained by the patients who were hospitalized.

It was found that the subjective assessment of exacerbation of pathological changes on the skin did not differentiate the studied patients in terms of 
acceptance of the illness, either. The patients who differed in terms of the subjectively estimated exacerbation of psoriasis measured using the SAPASI and VAS were not different from one another in the scope of that variable. Similar results were obtained in studies measuring the influence exerted by the exacerbation of psoriasis on acceptance of an illness using the PASI (Psoriatic Area Severity Index), being an objective scale - neither Zalewska, Miniszewska, Chodkiewicz, and Narbutt (2007), nor Basińska and Kasprzak (2012) found any statistically significant differences in the scope of acceptance of psoriasis in the scope of exacerbation of the illness.

It is worth noting that the results obtained using SAPASI and VAS, applied in our research, may differ from the actual exacerbation of psoriasis in the case of a given patient in connection with the fact that those scales are subjective, and that a patient assesses the quantity and outside appearance of pathological changes on the skin on their own and without the participation of a physician. It is also possible that the lack of acceptance of an illness influences the subjective assessment of the degree of exacerbation of changes on the skin.

The results obtained in the research being discussed using the Multidimensional Health Locus of Control Scale (MHLC) show that the patients suffering from psoriasis treated in the hospital setting were more frequently convinced that the state of their health is the result of the actions of other people, for example, of medical personnel, whereas outpatient clinic patients were in the majority of cases firmly convinced that their health locus of control was located internally. However, those differences were not statistically significant. Comparing the results obtained in this study using the MHLC test with the results for other clinical groups (on the basis of: Juczyński, 2001), it is possible to note that convictions concerning the internal and external health locus of control in the case of patients suffering from psoriasis were not as strong as, for example, in the case of the patients suffering from ischaemic heart disease, arterial hypertension, diabetes, and in the case of males who had suffered a myocardial infarction. What is interesting, in terms of belief that state of health is dependent on chance, patients with psoriasis were characterized by a slightly higher results in this scale than in the other above-mentioned clinical groups.

It was solely the males who had suffered a myocardial infarction who obtained a higher result in the scale of chance in comparison with the studied patients suffering from psoriasis (Juczyński, 2001; Opuchlik, Wrzesińska, \& Kocur, 2009). One can assume that this is due to the specific nature of the psoriasis, which is characterized by recurrences and connected with it common feeling of disappointment and despair. The exacerbation of changes on the skin is frequently con- nected with significant emotional strain, a high level of stress, or inappropriate diet. Not infrequently, the patients fail to see the connection between the illness becoming more acute and the factors mentioned above, which intensifies the feeling of a lack of control over the state of health, and consolidates the conviction that it is determined by chance. It also happens that the treatment being applied in the case of a strong emotional strain is not effective, and, in connection with that, control over the state of the skin becomes more difficult (Papadopoulos \& Bor, 1999).

There is a lot of evidence proving that the way in which the illness is perceived may exert an influence on the process of illness, and of treating a given medical condition itself. The attempt to investigate the ways in which psoriasis is perceived by patients treated in the hospital and outpatient clinic settings conducted in this study proved that the studied groups of patients were not significantly different from one another in that aspect, which means that hospitalized patients and those treated elsewhere than in the hospital setting shared similar feelings concerning their own medical condition. The results mentioned above are different from those obtained in the research of Janowski (2006), in which patients suffering from psoriasis differing in the aspect of the mode of treatment obtained significantly different results in four subscales. Hospitalized patients perceived their illness definitely more frequently than those treated in the outpatient clinic setting as a threat, an obstacle and a harm, simultaneously, getting more secondary benefits from it (Janowski, 2006). What is interesting, in another study, conducted by Janowski et al. (2009), patients suffering from various illnesses and treated in the hospital and outpatient clinic settings differed in the scope of perceiving an illness as well. Statistically significant differences were revealed in the subscales Benefit, Obstacle/Loss and Harm. Hospitalized patients obtained significantly higher results in each of those categories (Janowski et al., 2009). In other studies (Janowski, Steuden, \& Bogaczewicz) it was found that the assessment of psoriasis in the categories of Threat, Harm, and of Obstacle/Loss, is frequently connected with the more frequent experiencing of itching by the patients. The analysis of the average results obtained in the Disease Rating Scale in the present study suggests that the studied patients suffering from psoriasis, regardless of the mode of treatment, most frequently perceived their illness as a threat. Taking into consideration the profile of psoriasis, that result seems to be justified. In connection with the chronic character and burdensome course of the medical condition, psoriasis disturbs the state of equilibrium in the life of a patient, and frequently makes it unstable. Not infrequently, it also deprives patients of the sense of security and causes anxiety about their health and future. Furthermore, in the case of individuals suffering from der-
Determinants of psoriasis acceptance 
Marta Adamska,

Joanna

Miniszewska matological illnesses, a major feature is also obsessive checking of the state of the skin resulting from a strong anxiety about the exacerbation of changes, or their recurrence (Miniszewska, 2010).

Psoriasis was perceived least frequently by the studied individuals in the categories of benefits and values. That may mean that the studied patients experienced their illness as making it possible to enjoy a small number of secondary gains. They did not treat it, either, as a higher value, which helps to discover the meaning of life. Perhaps, in connection with the presence of unsightly psoriatic changes on the skin, the patients do not expect compassion from other people; they rather expect to be rejected, and such an attitude is not conducive to achieving gains from an illness in the form of interest and concern. Psoriasis as an illness not resulting in a direct threat to life may as well play no role in the revaluation of it (Janowski, 2006).

In the group of outpatient clinic patients, the exacerbation of psoriasis measured using the VAS was negatively correlated with acceptance of the illness. One may find the fact that no similar correlation was found in the case of hospitalized patients strange. The type of treatment is usually connected with the exacerbation of a given illness; therefore, hospitalization would in many cases mean stronger exacerbation of illness symptoms, and, consequently, a more negative attitude to a medical condition and the acceptance of it. Negative connections in the outpatient clinic study group were also discovered between perceiving an illness in the categories of threat and harm and the acceptance of it. The connections give rise to the conclusion that patients treated elsewhere than in the hospital setting find it difficult to accept the phenomenon which causes anxiety, destabilizes their current situation in life and is treated as an undeserved punishment. The internal health locus of control is the only variable which was positively correlated with acceptance of psoriasis among outpatient clinic patients. Being convinced that the control was internal in the case of individuals treated elsewhere than in the hospital setting may result in a stronger sense of security, and, first and foremost, agency, and, consequently, a higher level of acceptance of an illness. The state of the skin in the case of individuals suffering from psoriasis depends to a substantial degree on time-consuming procedures in the scope of nursing and treatment (among others, the application of ointments) undertaken by them, and diet. It is, therefore, understandable that the better a man understands the correlation between activity and the state of health, the greater the acceptance of their medical condition is observed.

In turn, in the group of hospitalized patients, being convinced that the state of health depends on chance was negatively connected with acceptance, which is understandable - the lack of faith in it being possible to control an illness, in particular, in hospital conditions, is bound to have negative consequences (Juczyński, 2001). It is curious why the internal or external health locus of control fails to be connected in that group with the acceptance of it. In the research of Zalewska et al. (2007) and Miniszewska (2011), the external health locus of control in the groups of hospitalized individuals was connected with a lower level of acceptance of an illness, and a more negative assessment of the quality of life. Perhaps a strong faith in the effectiveness of the actions of medical personnel and the milieu is connected with a higher level of concentration on an illness, and stronger disappointment in the case of recurrences.

Among the studied individuals treated in the hospital setting, the assessment of one's medical condition in the categories of a threat, harm, an obstacle/a loss and significance was negatively connected with acceptance of an illness. This result is not surprising - treating one's medical condition in such negative categories makes it impossible to become well adjusted to it.

In explaining the acceptance of the illness among all the patients, two variables were found to be significant. The largest contribution was that of the assessment of the illness in the categories of an obstacle and a loss, which caused a decrease in the acceptance of it. Numerous restrictions in life, difficulties in daily functioning, the loss of numerous opportunities, all three resulting from the fact of suffering from psoriasis, seem to be naturally connected with the lack of a positive attitude to this medical condition. Also, being convinced that the health locus of control is internal was revealed to determine the acceptance of one's pathological state. It is frequently emphasized in the literature that individuals whose health locus of control is situated internally cope with difficult situations better (Drwal, 1995; Juczyński, 2001).

Finally, an important limitation of this research should be mentioned, namely the small size of the studied group. Perhaps, if the group had been more numerous, it would have been possible to reveal other statistically significant correlations; however, it would certainly have made it possible to conduct more complex analyses and the determination of predictors for both groups separately. It is possible that identifying variables determining the degree of acceptance of the illness in separate groups would have explained the role of the health locus of control in correlation with the applied mode of treatment. Furthermore, in the future research controlling co-occurring diseases and the method of treatment being applied is very important. The latter may be significantly connected with the acceptance of the state of health. Here, what is worth mentioning is treatment using dithranol (which is a preparation beige in colour, with unpleasant odour and the consistency of a fat ointment). Ginsburg and Link (1989) pointed out 
that the constant feeling of not being clean, which is frequently a major feature of patients suffering from psoriasis, is connected not only with the existence of changes on the skin but, primarily, with the long-lasting application of dithranol and birch tar (Ginsburg \& Link, 1989). In turn, the new biological methods of treatment of psoriasis may make it possible to control the course of the illness, and, ipso facto, result in being satisfied with the therapy, and in improvement in the quality of life of patients (Miekoś-Zydek, Ryglowska-Cho, Lassota-Falczewska, Czyż, \& Kaszuba, 2006).

\section{CONCLUSIONS}

1. The mode of treatment of psoriasis (in the hospital and outpatient clinic settings) does not differentiate between the level of acceptance of the illness in the studied groups.

2. Individuals treated in the hospital setting do not differ from individuals treated in the outpatient clinic setting in the aspect of perceiving one's illness, and that of the subjective assessment of the exacerbation of changes on the skin.

3. In the group of hospitalized individuals, the assessment of the illness in the categories of an obstacle, a loss, harm and threat, and assigning a major meaning to it, as well as being convinced that health is determined solely by chance, is connected with the lower level of acceptance of restrictions resulting from psoriasis.

4. In the group of individuals treated in the outpatient clinic setting, it is solely the assessment of the illness in the categories of a threat and harm, and the subjective assessment of the exacerbation of changes to the skin that is connected with the lower level of acceptance of psoriasis. In turn, being convinced that one can influence one's health is connected with a higher level of acceptance of it.

5. The following determinants of acceptance of psoriasis in the group of all the studied individuals were revealed: the assessment of the illness in the categories of an obstacle/a loss, and the internal health locus of control.

6. The obtained results indicate that in the scope of psychological assistance for individuals suffering from psoriasis one needs to concentrate on, among other factors, the way in which they assess their illness, and the modification of it, and in working with patients treated in the outpatient clinic setting, on strengthening the feeling of being in control over one's health.

\section{RefERENCES}

Basińska, M. A., \& Kasprzak A. (2012). Związek między strategiami radzenia sobie ze stresem a akceptacją choroby w grupie osób chorych na łuszczycę [The relationship between strategies of coping with stress and acceptance of illness among patients with psoriasis]. Przeglad Dermatologiczny, 99, 692-700.

Basińska, M., \& Szymańska, L. (2013). Związek nastroju z cechami choroby u osób z łuszczycą [Relationship of mood with characteristics of the disease among a group of psoriasis patients]. Przeglad Dermatologiczny, 100, 146-153.

Basińska, M. A., \& Woźniewicz, A. (2012). Inteligencja emocjonalna chorych na łuszczycę jako wyznacznik akceptacji choroby [Emotional intelligence in psoriasis patients as a determinant of acceptance of illness]. Przeglad Dermatologiczny, 99, 202-209.

Drwal, R. Ł. (1995). Adaptacja kwestionariuszy osobowości. Wybrane zagadnienie i techniki [Adaptation of personality questionnaires. Selected issue and techniques]. Warszawa: PWN.

Dubertret, L., Mrowietz, U., Ranki, A., van de Kerkof, P.C.M., Chimenti, S., Lotti, T., \& Schafer, G. (2006). European patient perspectives on the impact of psoriasis: the EUROPSO patient membership survey. British Journal of Dermatology, 1, 729-736.

Ginsburg, I. H., \& Link, B. G. (1989). Feelings of stigmatization in patients with psoriasis. Journal of the American Academy of Dermatology, 20, 53-63.

Hawro, T., Janusz, I., Zalewska, A., \& Miniszewska J. (2011). Jakość życia i stygmatyzacja a nasilenie zmian skórnych i świądu u osób chorych na łuszczycę [Quality of life, stigmatization and the severity of skin lesions and itching in psoriasis patients]. In: T. Rzepa, J. Szepietowski, \& R. Żaba (eds.), Psychologiczne i medyczne aspekty chorób skóry [Psychological and medical aspects of skin diseases] (pp. 42-51). Wrocław: Wydawnictwo Cornetis.

Heszen, I., \& Sęk, H. (2012). Psychologia zdrowia [Health psychology]. Warszawa: PWN.

Jabłońska, S., \& Majewski, S. (2005). Choroby skóry $i$ choroby przenoszone droga ptciowa [Skin diseases and sexually transmitted diseases]. Warszawa: PZWL.

Janowski, K. (2006). Osobowościowe uwarunkowania radzenia sobie ze stresem tuszczycy [Personality determinants of coping with the stress of psoriasis]. Lublin: Wydawnictwo Polihymnia.

Janowski, K., Steuden, S., Kuryłowicz, J., \& Nieśpiałowska-Steuden, M. (2009). The Disease-Related Appraisals Scale: a tool to measure subjective perception of the disease situation. In: K. Janowski \& S. Steuden (eds.), Biopsychosocial Aspects of Health and Disease. Vol. 1 (pp. 108-125). Lublin: CPPP Scientific Press.

Janowski, K., Steuden, S., \& Bogaczewicz, J. (2013). Clinical and psychological characteristics of psoriasis patients reporting various frequencies of pruritus. International Journal of Dermatology, 53, 820-829.
Determinants of psoriasis acceptance 
Juczyński, Z. (2001). Narzędzia pomiaru w promocji i psychologii zdrowia [Measurement tools in the promotion and health psychology]. Warszawa: Pracownia Testów Psychologicznych.

Kostyła, M., Tabała, K., \& Kocur, J. (2013). Illness acceptance degree versus intensity of psychopathological symptoms in patients with psoriasis. Postępy Dermatologii i Alergologii, 3, 134-139.

Kulczycka, L., Sysa-Jędrzejowska, A., \& Robak, E. (2007). Jakość życia chorych na układowy toczeń
Marta Adamska, Joanna Miniszewska rumieniowaty ze szczególnym uwzględnieniem metodyki badań [Quality of life in patients with systemic lupus erythematosus, with a particular focus on research methodology]. Postępy Higieny i Medycyny Doświadczalnej, 61, 472-477.

Menter, A., \& Stoff, B. (2011). Psoriasis. London: Manson Publishing.

Miękoś-Zydek, B., Ryglowska-Cho, A., Lassota-Falczewska, M., Czyż, P., \& Kaszuba, A. (2006). Jakość życia w łuszczycy [Quality of life in psoriasis]. Postępy Dermatologii i Alergologii, 6, 273-277.

Miniszewska, J. (2010). Psychologiczne aspekty chorób skóry - psychodermatologia [Psychological aspects of skin diseases - psychodermatology]. In: E. Zasępa (ed.), Choroba, niepetnosprawność, cierpienie oraz postawy wobec nich - w teorii $i$ badaniach [IIlness, disability, suffering and attitudes towards them - in theory and research] (pp. 230-244). Warszawa: Wyd. Akademii Pedagogiki Specjalnej.

Miniszewska, J. (2011). Jakość życia i poziom zasobów osobistych u osób chorych na łuszczycę [Quality of life and the level of personal resources in patients with psoriasis]. In: T. Rzepa, J. Szepietowski, \& R. Żaba (eds.), Psychologiczne i medyczne aspekty chorób skóry [Psychological and medical aspects of skin diseases] (pp. 52-64). Wrocław: Wydawnictwo Cornetis.

Miniszewska, J., Juczyński, Z., Ograczyk, A., \& Zalewska, A. (2013). Health-related quality of life in psoriasis: important role of personal resources. Acta Dermato-Venereologica, 93, 551-556.

Opuchlik, K., Wrzesińska, M., \& Kocur, J. (2009). Ocena poziomów stylów radzenia sobie ze stresem i poczucia umiejscowienia kontroli zdrowia u osób z chorobą niedokrwienną serca i nadciśnieniem tętniczym [The assessment of the level of coping style and health locus of control in patients with coronary heart disease and hypertension]. Psychiatria Polska, 2, 235-245.

Orzechowska, A., Talarowska, M., Zboralski, K., Florkowski, A., \& Gałecki, P. (2013). Subiektywna ocena objawów i efektów leczenia a natężenie stresu i poziomu lęku wśród pacjentów z wybranymi chorobami skóry i układu pokarmowego [Subjective evaluation of symptoms and effects of treatment and the intensity of the stress and anxiety levels among patients with selected diseases of the skin and gastrointestinal tract]. Psychiatria Polska, 2, 225-237.

Pacan, P., Szepietowski, J., \& Kiejna, A. (2002). Wpływ czynników psychicznych na przebieg łuszczycy [The influence of psychological factors on psoriasis]. Przeglad Dermatologiczny, 5, 401-408.

Parafianowicz, K., Sicińska, J., Moran, A., Szumański, J., Staniszewski, K., Rudnicka, L., \& Kokoszka, A. (2010). Współwystępowanie zaburzeń psychicznych w łuszczycy: doniesienie wstępne [Comorbidity of mental disorders in psoriasis: a preliminary report]. Psychiatria Polska, 1, 119-126.

Papadopoulos, L., \& Bor, R. (1999). Psychological Approaches to Dermatology. London: The British Psychological Society.

Sampogna, F., Sera, F., Mazzotti, E., Pasquini, P., Picardi, A., Abeni, D., \& the IDI Multipurpose Psoriasis Research on Vital Experiences (IMPROVE) Study Group (2003). Performance of the Self-administered Psoriasis Area and Severity Index in Evaluating Clinical and Sociodemographic Subgroups of Patients With Psoriasis. Archives of Dermatology, 139, 353-358.

Sampogna, F., Tabolli, S., Abeni, D., \& the IDI Multipurpose Psoriasis Research on Vital Experiences (IMPROVE) investigators (2007). The impact of changes in clinical severity on psychiatric morbidity in patients with psoriasis: a follow up study. British Journal of Dermatology, 157, 508-513.

Walker, C., \& Papadopoulos, L. (2005). Psychodermatology. The psychological impast of skin disorders. Cambrige: Cambrige University Press.

Zalewska, A., Miniszewska, J., Chodkiewicz, J., \& Narbutt, J. (2007). Acceptance of chronic illness in psoriasis vulgaris patients. Journal of the European Academy of Dermatology and Venereology, 21, 235-242. 